\title{
UWARUNKOWANIA KREACJI TURKUSOWYCH ORGANIZACJI W POLSCE
}

DOI: 10.33141/po.2019.10.02

\section{Ryszard Borowiecki, Zbigniew Olesiński}

\section{Wprowadzenie}

0 bszar zainteresowań nauki o zarządzaniu i jakości rozprzestrzenił się w ostatnich latach na problematykę systemów wartości, ochrony środowiska, innowacji i inne. Zasadniczą przyczyną zmian, jak się wydaje, był wzrost roli i znaczenia usług $\mathrm{w}$ porównaniu $\mathrm{z}$ wcześniejszym okresem sprzed 40-50 lat, kiedy to wiodące znaczenie, także $\mathrm{w}$ Polsce, miały organizacje produkcyjne, zwłaszcza przemysłu maszynowego.

Właśnie w tym kontekście pojawiły się procesy decentralizacji struktur organizacyjnych i wystąpiło przejawianie się tendencji do spłaszczenia struktur organizacyjnych, wzrostu roli i znaczenia struktur zdecentralizowanych, horyzontalnych. W tym kontekście $\mathrm{w}$ warunkach polskich $\mathrm{z}$ końcem ubiegłego wieku zaczęły nabierać znaczenia organizacje małe, przedsiębiorcze, kreatywne, coraz częściej w swym funkcjonowaniu opierające się na zasadach outsourcingu i benchmarkingu, szybko i efektywnie nawiązujące współpracę z organizacjami ze swego otoczenia, tworząc energicznie rozwijające się sieci współpracy organizacyjnej i klastry. Wzrosła rola i znaczenie kreatywnych zespołów pracowniczych, zwłaszcza wśród zespołów badawczych, projektowych, zespołów programistów komputerowych, ale i w ogóle zespołów pracowniczych, zwłaszcza w organizacjach, w których występowały zaawansowane technologie kolejnej fali rewolucji przemysłowej zwanej coraz częściej epoką Przemysłu 4.0.

Tym samym znacznie dynamiczniejszemu przebiegowi podlegały cykle rozwoju organizacji. Nowo powstające przedsiębiorstwa miały i mają szanse na szybki rozwój, ale równie szybko mogły i mogą podlegać likwidacji. Ten wczesny okres funkcjonowania organizacji charakterystyczny jest zwłaszcza w kontekście specyficznych relacji między pracownikami tworzącymi przedsiębiorstwo. Zwiększone znaczenie umiejętności pracowników i mniejsze znaczenie zajmowanych stanowisk stały się podstawą do sformułowania pojęcia tzw. turkusowych organizacji. U podstaw założeń ich funkcjonowania leży brak hierarchii w zarządzaniu. 
Celem artykułu jest wskazanie mechanizmów wewnątrzorganizacyjnych, które mają wpływ na zmiany występujące $\mathrm{w}$ obecnych strukturach organizacyjnych. W spółcześnie obserwuje się ewolucję w wielu kierunkach (Laloux, 2015; Rzepka, Olak, 2017), tak ku strukturom scentralizowanym, jak i zdecentralizowanym. Autorzy chcą wykazać, że najbardziej efektywne zmiany wiodą ku organizacjom zdecentralizowanym - turkusowym.

Główne pytanie badawcze odnosi się do tego, jakie czynniki mają wpływ na inicjowanie zmian wewnątrzorganizacyjnych kierunku transformacji do struktur organizacji turkusowych. Pierwsze pytanie pomocnicze dotyczy roli i znaczenia zwinności pracowników i organizacji $\mathrm{w}$ procesie zmian wewnątrzorganizacyjnych $\mathrm{w}$ kierunku transformacji do struktur organizacji turkusowej. Drugie pytanie pomocnicze dotyczy roli i znaczenia w powyższym procesie współpracy międzyorganizacyjnej. Natomiast trzecie pytanie pomocnicze dotyczy roli i znaczenia kreacji wewnątrzorganizacji tak zwanych miękkich czynników zarządzania.

Metodą badawczą prowadzącą do realizacji tak sformułowanych celów i pytań jest krytyczna analiza literatury (Appelo, 2016; Blikle, 2018; Siuta-Tokarska, 2015; Kozina, Pieczonka, 2017), a także analiza przeprowadzonych już badań dotyczących skłonności do zmian przejawianych przez respondentów z przedsiębiorstw województwa podkarpackiego. Bezpośrednią podstawą rozważań były badania przeprowadzone przez A. Rzepkę i A. Olaka (2017) w porównaniu z wcześniejszymi badaniami (Olesiński, 2005; 2010).

\section{W poszukiwaniu nowych form organizacji}

A nalizując dynamikę zmian, tak społecznych, jak i gospodarczych oraz politycznych, można mechanizm tych zmian określić jako bardzo szybki i jednocześnie złożony. Jednym z bezpośrednich czynników sprawczych zmian jest rozwój i upowszechnienie Internetu, a szerzej rzecz ujmując - wzrost zastosowań informatyki. Sytuacja ta w naturalny sposób sprzyja powstawaniu i rozwojowi małych organizacji, które dzięki informatyce z łatwością mogą nawiązać współpracę z innymi organizacjami, co sprzyja rozwojowi benchmarkingu i outsourcingu i co skutkuje rozwojem oraz instytucjonalizacją otoczenia organizacji w skali lokalnej (gmina), regionalnej (województwo), krajowej, a w pewnych warunkach również globalnej.

W omawianej sytuacji dominują organizacje małe, bardziej naturalne są struktury organizacyjne płaskie, zdecentralizowane, horyzontalne, sprzyjające innym relacjom między uczestnikami organizacji (pracownicy, członkowie) niż w organizacjach dużych, liczących po kilka, a nawet kilkadziesiąt tysięcy uczestników, scentralizowanych, wertykalnych, hierarchicznych.

Proces decentralizacji dużych struktur organizacyjnych zainicjowany został jeszcze przed upowszechnieniem Internetu, w latach sześćdziesiątych i siedemdziesiątych ubiegłego wieku wraz ze wzrostem roli i znaczenia usług. Można zatem sformułować pogląd, że proces wzrostu roli i znaczenia decentralizacji struktur organizacyjnych zapoczątkowany impulsem związanym z rozwojem sfery usług doznał kolejnego impulsu wraz z rozwojem informatyzacji, której szczególnie istotnym elementem jest Internet Rzeczy (IoT - Internet of Things), z którym wiąże się system informatyczny $5 \mathrm{G}$.

Wyżej wymienione dwa procesy zbiegają się z kolejnym fenomenem, którym jest wzrost roli i znaczenia przejawu indywidualizmu postaw, poglądów, zapatrywań coraz liczniejszej grupy ludzi zainteresowanych swobodą zachowań i wypowiedzi, wolnością i pluralizmem poglądów, aspiracji, oczekiwań (Borowiecki, Siuta-Tokarska, 2008; Laloux, 2015; Appelo, 2016; Skrzypek, 2017; Ziębicki, 2017; Juchnowicz, 2017; Kalwa-Rojczyk, 2018).

\section{Identyfikacja turkusowych organizacji}

B adania empiryczne prowadzone w Polsce w ograniczonym zakresie identyfikują postawy pracownicze typowe dla zachowań w organizacji turkusowej.

A.J. Blikle (2018, s. 79-85) w swojej publikacji podaje przykłady polskich turkusowych organizacji, w tym firmę "Marco" z Gliwic, założoną w 2000 roku przez M. Ślibodę, która produkuje etykiety, uszczelki, podkładki i opakowania. Około 50 niewielkich, ale bardzo nowoczesnych linii produkcyjnych obsługuje 20 operatorów. Realizują kilkanaście planów produkcyjnych jednocześnie. Firma zatrudnia ponad 80 osób i posiada oddziały handlowe w Brnie (Czech), Sofii (Bułgaria), a także oddział produkcyjny w Toruniu i magazyn w Usti (Czechy). Firma zasadniczo nie posiada struktur kierowniczych.

Inna firma opisana przez A.J. Bliklego (2018, s. 82-85) to „Brewa”, założona w 2015 roku przez grupę osób, w tym M. Borowiaka. Oferuje ona rozwiązania oparte na czystych odnawialnych źródłach energii, specjalizując się w elektrowniach słonecznych (instalacje fotowoltaiczne), a także wykonuje instalacje systemów do zarządzania energią $\mathrm{z}$ wykorzystaniem oświetlenia LED oraz doborem odpowiedniej mocy ciepła i mocy energii elektrycznej. Firma liczy dwa zespoły, po 5 osób, zasadniczo bez struktur kierowniczych.

Badania empiryczne wskazują, że można poszukiwać przejawów funkcjonowania turkusowych organizacji szczególnie w nowo tworzonych przedsiębiorstwach, w tym w środowisku akademickim w organizacjach typu spin-off i spin-out oraz w startupach innowacyjnych.

W przytoczonych wyżej przykładach widać, że startupy tworzą kilkuosobowe, zintegrowane grupy koleżeńskie, co również na ogół występuje w przedsiębiorstwach spin-off i spin-out.

J. Appelo (2016, s. 41) w swojej pracy o nowym zarządzaniu eksponuje rolę i znaczenie zwinnych metod zarządzania w zespołach programistów komputerowych. Zjawisko zwinności jest znacznie szersze niż programowanie komputerowe, stąd celowe jest zwrócenie uwagi na określenie samej zwinności. 
„Pojęcie zwinności wykształciło się w dziedzinie produkcji. Szybko jednak rozszerzono jego założenia do innych funkcji przedsiębiorstwa, co skutkowało powstaniem terminu „zwinne przedsiębiorstwo” (Goldman i in., 1995, s. 34-42). Obecnie funkcjonuje bardzo wiele opinii dotyczących sposobu rozumienia pojęcia zwinności”. To pogląd A. Olaka, zajmującego się od szeregu lat badaniem zwinności w polskich przedsiębiorstwach (Olesiński i in., 2017, s. 46).

J. Appelo (2016) zawęża rozumienie zwinności do prac zespołów programistów komputerowych i fenomen zwinności łączy z powstaniem Rapid Application Development (RAD). „Łączyło ono w sobie niektóre z formalnych technik „wagi ciężkiej” inżynierii oprogramowania (takie jak tablice zmian, inspekcje i metryki) z działaniami praktycznymi (jak prototypowanie, ewolucyjne tworzenie oprogramowania oraz intensywna współpraca z klientem)". Wydaje się, że J. Appelo (2016, s. 47) nadmiernie akcentuje przełom w postaci powstania rewolucyjnej metody zarządzania 3.0, choć tak naprawdę wyrasta ona $\mathrm{w}$ dużym stopniu $\mathrm{z}$ dotychczasowego dorobku nauki zarządzania i jakości.

Po tych kilku ogólnych uwagach, pamiętając, że zwinność to część pojęcia turkusowej organizacji, autorzy chcieliby przytoczyć wyniki badań A. Rzepki i A. Olaka (2017). Badaniami tymi objęto 231 respondentów, z celowo dobranych 231 przedsiębiorstw województwa podkarpackiego. Do analizy przyjęto odpowiedzi 202 respondentów (tab. 1).

Wyniki badań są bardzo optymistyczne. Należy wziąć pod uwagę, iż odpowiedzi udzielali respondenci z firm współpracujących w stowarzyszeniach przedsiębiorców, a więc, ogólnie rzecz biorąc, o ugruntowanej pozycji. Odpowiedzi udzielali przeważnie przedstawiciele kierownictwa, czyli osoby na ogół kreatywne i przedsiębiorcze.

$\mathrm{Z}$ danych zawartych w kolumnie pierwszej tabeli 1, a mianowicie odpowiedzi „Bardzo łatwo”, należy przypuszczać, iż odpowiedzi były udzielone przez osoby otwarte, przedsiębiorcze, kreatywne. Można więc domniemywać, iż są one skłonne angażować się w eksperymenty menedżerskie z zakresu samozarządzania.

Analizując z kolei dane kolumny pierwszej tabeli 2, dokonując podobnych zastrzeżeń jak przy kolumnie pierwszej w tabeli 1, można uznać z dużym przybliżeniem, że w kilku, a nawet kilkunastu procentach analizowanych przedsiębiorstw można się dopatrzeć pewnych przejawów samozarządzania, charakterystycznych dla

Tabela 1. Łatwość dostosowania się do nowych warunków $(\mathrm{n}=202)$, dane w \%

\begin{tabular}{|c|c|c|c|c|c|}
\cline { 2 - 5 } & Bardzo tatwo & Latwo & $\begin{array}{c}\text { Trudno } \\
\text { powiedzieć }\end{array}$ & Trudno & Bardzo trudno \\
\hline $\begin{array}{c}\text { Dostosowanie się do } \\
\text { wymogów nowego sprzętu }\end{array}$ & 28,2 & 49,2 & 7,9 & 12,4 & 2 \\
\hline $\begin{array}{c}\text { Dostosowanie się do pracy } \\
\text { z zespołem praktykującym } \\
\text { inne metody pracy }\end{array}$ & 19,8 & 53,5 & 10,9 & 14,9 & 1 \\
\hline $\begin{array}{c}\text { Jednoczesna praca nad } \\
\text { kilkoma projektami }\end{array}$ & 10,9 & 47,5 & 20,3 & 17,3 & 4 \\
\hline $\begin{array}{c}\text { Dostosowanie się do } \\
\text { nowych procedur pracy }\end{array}$ & 15,3 & 51 & 16,3 & 14,4 & 3 \\
\hline $\begin{array}{c}\text { Dobre relacje z osobami } \\
\text { z różnych działów }\end{array}$ & 33,7 & 43,6 & 8,4 & 9,9 & 4,5 \\
\hline
\end{tabular}

Źródto: Rzepka, Olak, 2017

Tabela. 2. Szybkość dostosowania się do nowych warunków $(n=202)$, dane w \%

\begin{tabular}{|c|c|c|c|c|c|}
\cline { 2 - 5 } & Bardzo szybko & Szybko & $\begin{array}{c}\text { Trudno } \\
\text { powiedzieć }\end{array}$ & Wolno & Bardzo wolno \\
\hline $\begin{array}{c}\text { Nagłe przejście z pracy } \\
\text { nad jednym projektem } \\
\text { do pracy nad innym }\end{array}$ & 13,9 & 55 & 15,8 & 12,9 & 2,5 \\
\hline $\begin{array}{c}\text { Zmiana własnego sposobu } \\
\text { wykonywania zadań w celu } \\
\text { dostosowania się do metod } \\
\text { pracy wspótpracowników }\end{array}$ & 10,4 & 57,4 & 16,8 & 12,9 & 2,5 \\
\hline $\begin{array}{c}\text { Zmiana planów dotychczasowej } \\
\text { pracy, gdy potrzebne zasoby } \\
\text { są nagle nieosiągalne }\end{array}$ & 9,9 & 55,9 & 23,8 & 8,4 & 2 \\
\hline
\end{tabular}

Źródło: Rzepka, Olak, 2017 
turkusowych organizacji. Jest to kilka procent organizacji $\mathrm{z}$ tendencjami do ewolucji (być może powolnej) ku turkusowym organizacjom. Stąd słuszność koncepcji A.J. Bliklego, który stwierdził, że zidentyfikował w Polsce kilka takich organizacji, z których dwie scharakteryzował bardziej dokładnie. Powyższe potwierdza zasadność stosowania metody case study i obserwacji uczestniczącej. Stąd stosownie do rangi i znaczenia cytowanych badań wydaje się uprawnione udzielenie pozytywnej odpowiedzi na pierwsze pomocnicze pytanie badawcze.

\section{Próba komparatystyki}

W badaniach A. Rzepki i A. Olaka przeprowadzono obok zwinności badanie wiedzy pracowników o współpracy ich firmy z innymi organizacjami i instytucjami w celu wymiany wiedzy i informacji. Wyniki badań przedstawia tabela 3. Analizując te dane, zwraca uwagę to, że ponad $70 \%$ ankietowanych przedsiębiorstw utrzymywało współpracę z innymi przedsiębiorstwami.

W badaniach przeprowadzonych w latach 2002-2005 w przedsiębiorstwach Polski Wschodniej niewiele ponad $20 \%$ przedsiębiorstw deklarowało taką współpracę (Olesiński, 2005, s. 88).

Przyjmując, że badania są trudno porównywalne, jednak są podstawy do twierdzenia, że w Polsce w ciągu ostatnich lat nastąpił wzrost współpracy międzyorganizacyjnej (tab. 4).

W przeprowadzonych badaniach na Podkarpaciu znalazły się pytania dotyczące oceny relacji międzyorganizacyjnych (Rzepka, 2018, s. 208-210). Ankietowani otrzymywali pytania: „Czy relacje niezwiązane z rygorami pracy i proceduralnymi wymogami sprzyjają kształtowaniu szacunku wobec partnera biznesowego, uznaniu jego kompetencji, respektu dla jego lojalności?”; „Czy relacje niezwiązane $\mathrm{z}$ rygorem konieczności i proceduralnymi wymogami sprzyjają poprawie relacji w firmie, wzrostowi jej kompetencji, rzetelności i wiedzy?”; „Czy nieformalne relacje sprzyjają poprawie samopoczucia, wzmacniają przekonanie o własnych kompetencjach, wzmacniają pewność w pracy, zwiększają satysfakcję z wykonywanej pracy?” oraz „Czy współpraca firmy $\mathrm{z}$ innymi organizacjami zwiększa jej zasoby danych, informacji, wiedzy?". Odpowiedzi były udzielane w skali od 1 do 7 , gdzie 1 oznacza nigdy, a 7 zawsze. Przeważająca liczba w wynikach badań to wartości między 4 a 5 .

Przy pomiarze kapitału społecznego w 5 klastrach zlokalizowanych: trzy w województwie śląskim, dwa w województwie świętokrzyskim, przeprowadzonym w latach 2006-2008 w łącznie 193 przedsiębiorstwach, osiągnięto w skali 1-7 podobne wyniki (Olesiński, 2010, s. 138).

Zasadniczo dane $\mathrm{z}$ obu badań są trudno porównywalne, jednakże warto zwrócić uwagę, że badania przedsiębiorstw $\mathrm{w}$ klastrach przeprowadzono $\mathrm{w}$ przedsiębiorstwach od wielu lat ze sobą współpracujących. Słuszna jest zatem konkluzja, że w badaniach przedsiębiorstw w województwie podkarpackim nastąpiła podobna integracja w 2017 roku, jak w przedsiębiorstwach intensywnie ze sobą współpracujących 10 lat wcześniej. Należy dodać, że rozwój współpracy przedsiębiorstw sprzyja wzrostowi zaufania, wzrostowi kapitału społecznego i wiedzy istotnych dla wzrostu innowacyjności i kreatywności przedsiębiorstw.

Jeśliby korelować cechę zwinności jako cechę wiodącą ku turkusowej organizacji, to wydaje się uprawnione zwrócenie uwagi na rolę współpracy międzyorganizacyjnej i wzrost tak zwanych miękkich czynników zarządzania (wiedza, zaufanie, kapitał społeczny) na umacnianie się tendencji w części organizacji do rozwoju ku samoorganizacji i spłaszczaniu struktur. Tym samym zasadne jest również podkreślenie wpływu współpracy międzyorganizacyjnej (drugie pomocnicze pytanie badawcze) i miękkich czynników zarządzania (trzecie pomocnicze pytanie badawcze) na możliwość przejawiania się samozarządzania $\mathrm{w}$ badanych organizacjach, a tym samym wskazanie, że wzrost zwinności, wzrost współpracy międzyorganizacyjnej i wzrost miękkich czynników zarządzania prowadzi ku kształtowaniu się turkusowych organizacji (główne pytanie badawcze).

Tabela 3. Wiedza pracowników o wspótpracy ich firmy z innymi organizacjami i instytucjami w celu wymiany wiedzy $\mathrm{i}$ informacji $(\mathrm{n}=202$, dane $\mathrm{w} \%)$

\begin{tabular}{|c|c|c|c|c|c|c|c|}
\hline $\begin{array}{c}\text { Częstotliwość } \\
\text { kontaktów } \\
\text { Rodzaj organizacji }\end{array}$ & Nigdy & $\begin{array}{c}\text { Raz na } \\
\text { kilka lat }\end{array}$ & $\begin{array}{c}\text { Kilka razy } \\
\text { w roku }\end{array}$ & $\begin{array}{c}\text { Kilka razy } \\
\text { w kwartale }\end{array}$ & $\begin{array}{c}\text { Kilka razy } \\
\text { w miesiącu }\end{array}$ & $\begin{array}{c}\text { Kilka razy } \\
\text { w tygodniu }\end{array}$ & $\begin{array}{c}\text { Raz } \\
\text { w tygodniu }\end{array}$ \\
\hline Przedsiębiorstwo & 24,8 & 5,4 & 21,8 & 12,9 & 15,3 & 13,9 & 5,9 \\
\hline Firma doradcza & 34,7 & 5,4 & 27,7 & 11,4 & 13,4 & 4,5 & 3 \\
\hline Ośrodek naukowy & 67,3 & 4 & 15,3 & 5,9 & 5 & 1,5 & 1 \\
\hline Gmina & 36,1 & 7,9 & 19,8 & 10,9 & 11,4 & 9,9 & 4 \\
\hline Powiat & 40,1 & 10,9 & 21,8 & 12,4 & 6,9 & 5 & 3 \\
\hline Województwo & 56,9 & 11,9 & 18,8 & 5 & 3,5 & 2,5 & 1,5 \\
\hline Agencja rządowa & 78,2 & 6,4 & 7,9 & 2,5 & 2,5 & 2 & 0,5 \\
\hline
\end{tabular}

Źródło: Rzepka, Olak, 2017 


\section{Struktury organizacyjne turkusowych organizacji}

Coraz liczniejsze grupy pracowników oczekują satysfakcjonującej pracy, w której mogliby realizować swoje marzenia, aspiracje i ambicje. Te i złożone w oddziaływaniu procesy społeczne, ekonomiczne, polityczne, technologiczne sprzyjają kształtowaniu nowego modelu organizacji, określonego przez F. Lalouxa (2015) jako turkusowa, ewolucyjna organizacja, inna niż typowa dla epoki przemysłowej, organizacja określana jako oranżowa i inna niż wcześniejsza przed epoką przemysłową, dominującą organizacją bursztynową. Prognozowana dla turkusowych organizacji przyszłość jest zaprezentowana na przykładzie modeli z rysunków 1-3.
Analiza proponowanych przez F. Lalouxa turkusowych struktur organizacyjnych wskazuje, że przedstawione na rysunkach 1-3 schematy istotnie różnią się od schematów dotychczasowych organizacji. Wyraźnie widać, że proponowany schemat próbuje oddać istotę zachodzących zmian, a przede wszystkim swobodę zachowań zespołów pracowniczych. W szczególności komunikatywny jest pierwszy schemat przedstawiający strukturę organizacyjną małej organizacji, złożonej z kilku osób, jak w mikroprzedsiębiorstwie (np. rodzinna firma, sklep spożywczy) (Hopej-Tomaszycka; Hopej, 2018) czy w firmie „Brewa” (10-osobowa).

Rysunek 2 przedstawia sytuację typową dla organizacji średnich, (do 249 zatrudnionych). Schemat ten dobrze odpowiada strukturze organizacyjnej firmy „Marco” (około 80 osób).
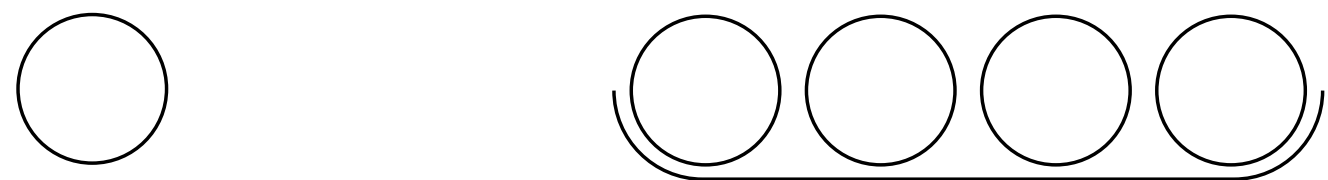

Rys. 1. Model matej turkusowej organizacji Źródto: opracowanie własne

Rys. 2. Model turkusowej organizacji średniej wielkości Źródto: opracowanie wtasne

Tabela 4. Charakterystyka współpracy ze względu na korzystanie z pomocy przy realizacji zadania

\begin{tabular}{|c|c|c|c|c|c|c|c|}
\hline $\begin{array}{c}\text { Częstotliwość } \\
\text { współpracy } \\
\text { Rodzaj organizacji }\end{array}$ & $\begin{array}{c}\text { Bardzo } \\
\text { często } \\
\text { (codziennie) }\end{array}$ & $\begin{array}{c}\text { Często } \\
\text { (kilka razy } \\
\text { w tygodniu) }\end{array}$ & $\begin{array}{c}\text { Czasami } \\
(\text { raz } \\
\text { w miesiącu) }\end{array}$ & $\begin{array}{l}\text { Rzadko } \\
\text { (raz na } \\
\text { kwartał) }\end{array}$ & $\begin{array}{l}\text { Sporadycznie } \\
\text { (raz na rok) }\end{array}$ & $\begin{array}{c}\text { Brak } \\
\text { odpowiedzi }\end{array}$ & Razem \\
\hline Samorząd gminy & 5 & 28 & 13 & 10 & 4 & 230 & 290 \\
\hline Samorząd powiatu & 2 & 31 & 13 & 11 & 6 & 227 & 290 \\
\hline Samorząd wojewódzki & 2 & 18 & 3 & 16 & 9 & 242 & 290 \\
\hline Urząd wojewódzki & 5 & 23 & 8 & 15 & 9 & 230 & 290 \\
\hline Urząd marszałkowski & 4 & 20 & 8 & 8 & 7 & 243 & 290 \\
\hline Urząd miasta & 8 & 26 & 19 & 3 & 4 & 230 & 290 \\
\hline Samorząd terytorialny & 3 & 24 & 8 & 8 & 8 & 230 & 290 \\
\hline $\begin{array}{c}\text { Agencja } \\
\text { Restrukturyzacji }\end{array}$ & 2 & 1 & 3 & 9 & 5 & 270 & 290 \\
\hline Fundacja Promocji & 5 & 12 & 3 & 12 & 4 & 254 & 290 \\
\hline $\begin{array}{c}\text { Inkubator } \\
\text { Przedsiębiorczości }\end{array}$ & 6 & 12 & 9 & 10 & 0 & 253 & 290 \\
\hline Media & 16 & 24 & 10 & 15 & 4 & 223 & 290 \\
\hline Szkoły & 13 & 21 & 7 & 11 & 7 & 231 & 290 \\
\hline Banki & 35 & 26 & 5 & 4 & 0 & 220 & 290 \\
\hline Przedsiębiorstwa & 44 & 32 & 4 & 7 & 2 & 201 & 290 \\
\hline
\end{tabular}

Źródło: Olesiński, 2005 


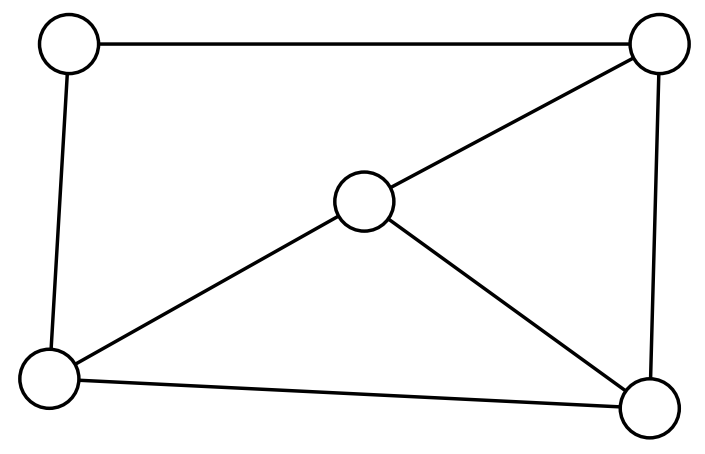

Rys. 3. Model dużej turkusowej organizacji Źródto: opracowanie własne

Trzeci schemat struktury organizacyjnej turkusowych organizacji odpowiada dużym przedsiębiorstwom przedstawionym w monografii F. Lalouxa, jak „Butzorg” czy „Morning Star” (rys. 3). Struktury takie dziś w Polsce raczej nie występują. F. Laloux daje przykład turkusowej organizacji, jaką jest „AES”, zatrudniającej 40 tys. pracowników. Firma ta produkuje i dostarcza energię elektryczną, posiada fabryki w 12 krajach na całym świecie. Samozarządzanie w tej firmie odpowiada schematowi z rysunku 3, określonemu jako duża organizacja, o długim łańcuchu wartości.

\section{Drogi restrukturyzacji ku turkusowej organizacji}

$\mathbf{P}$ owstaje pytanie: „Jak dokonać reorganizacji dotychczasowych struktur organizacyjnych typowych dla epoki przemysłowej w struktury turkusowe?". Z licznych badań empirycznych wynika, że na ogół nie dokonują się one jednorazowo. Zasadniczo zmiana ze struktury hierarchicznej w płaską jest to raczej proces dokonujący się etapami. Nawet jeśli przyjmiemy sytuację, że tworzymy całkiem nową strukturę organizacyjną, co związane jest na przykład $z$ procesem inwestycyjnym, to nie tyle interesują nas pewne rozwiązania modelowe, lecz określone względy praktyczne i pewne dotychczasowe doświadczenie. Bardziej zasadne wydaje się zatem definiowanie procesu ewolucji struktur organizacyjnych. W praktyce, uwzględniając oczekiwania inwestorów, uwarunkowania miejsca lokalizacji inwestycji czy wręcz pewną ostrożność, preferowane są modele struktur organizacyjnych w części inspirowane modelami wcześniej stosowanymi, wywodzącymi się z epoki przemysłowej (oranż), ale też w niektórych przejawach (np. rola i pozycja kierownictwa organizacji) z epoki jeszcze wcześniejszej, przedprzemysłowej (bursztynowa). Pogląd nasz na kwestię dróg restrukturyzacji jest inny niż u F. Lalouxa (2015, s. 309), który twierdzi, że albo powstaje już turkusowa struktura, albo stara jest gruntownie zmieniona $\mathrm{z}$ inspiracji kierownictwa. Autorzy podzielają pogląd, że możliwa jest trzecia droga, pewnego rodzaju przetargu między pracownikami oraz kierownictwem polegająca na osiąganiu konsensusu na drodze ku powstaniu turkusowej struktury.

Podane w artykule przykłady turkusowych organizacji wskazują raczej na incydentalne okoliczności, jak chociażby relacje koleżeńskie $\mathrm{w}$ organizacji, niechęć do respektowania kierownictwa ze względu na charakter wykonywanej pracy, na przykład przy akwizycji, niż stanowczy zamysł konstrukcji samozarządzającej organizacji.

W swojej monografii „Doktryna jakości. Wydanie II turkusowe. Rzecz o turkusowej samoorganizacji” A.J. Blikle (2018, s. 79) wskazuje dwa przykłady organizacji działających w Polsce, spełniających kryteria organizacji turkusowych. Jest to obecnie jedynie ewenement, który jednak ma szanse się rozwinąć, wart jest pogłębionych obserwacji, ale też stymulowania ze strony organizacji wsparcia biznesu, środowisk eksperckich i naukowych.

\section{Podsumowanie}

$\mathbf{P}$ rzedstawione $\mathrm{w}$ artykule rozważania prowadzą do ostrożnego, ale jednak jednoznacznego stwierdzenia wzrostu roli i znaczenia tak zwanych turkusowych organizacji. Znane nam badania empiryczne, z których kilka wybranych zostało przytoczonych, zdają się potwierdzać wzrost przejawiania się postaw prosamozarządzających, zwłaszcza wśród młodzieży i lepiej wykształconej części pracowników. Wśród mechanizmów, które mają wpływ na zmiany występujące w strukturach organizacyjnych są tendencje do decentralizacji dużych struktur oraz większe dążenie do samozarządzania, jakie są charakterystyczne dla obecnych przedsiębiorstw.

Według obserwacji autorów i z przytoczonych badań empirycznych można sformułować wniosek, że jednym z czynników mających wpływ na dokonywanie zmian wewnątrzorganizacyjnych jest inicjowanie przez zespoły pracownicze przedsięwzięć wiodących ku wzrostowi samodzielności tak poszczególnych pracowników, jak i całych wyodrębnionych zespołów, na przykład projektowych. W przypadku negatywnej oceny przez kierownictwo powyższych inicjatyw nie jest możliwa pełna ich realizacja, ale tu należy podkreślić, że w pewnym zakresie i w pewnych określonych zespołach, bez naruszenia scentralizowanej struktury, takie inicjatywy mogą zmierzać w kierunku turkusowych zespołów, zwłaszcza w środowisku organizacji innowacyjnych, jak startupy i wspomniane wyżej zespoły projektowe. Kolejnym wnioskiem, który rysuje się dość wyraźnie z przeprowadzonych dociekań literatury, jak też analiz empirycznych, jest kwestia uznania większej skłonności do samozarządzania w przedsiębiorstwach nowo zakładanych. Odpowiedzialność pracownicza tym rośnie, im przedsiębiorstwa podlegają większemu rozwojowi.

Wydaje się możliwe wsparcie wyżej przedstawionych tendencji przez organizacje wsparcia biznesu, 
firmy doradcze, środowisko nauki. Celowe zatem jest też zintensyfikowanie badań wybranych środowisk organizacji dla określenia trendów i tendencji zmian ku turkusowym organizacjom.

W artykule wskazano na procesy, takie jak poszukiwanie warunków dla innowacji w organizacjach, które występują w warunkach samozarządzania (zespoły programistów opisywane przez J. Appelo) czy zespoły koleżeńskie w startupach. Stąd celowe jest poszukiwanie i stosowanie takich rozwiązań przy wsparciu publicznym dla przedsiębiorstw, tendencji do wzrostu produktywności i proinnowacyjnych postawach, zwłaszcza młodych pracowników.

\section{prof. dr hab. Ryszard Borowiecki \\ Akademia WSB w Dąbrowie Górniczej \\ Wydziat Nauk Stosowanych \\ ORCID: 0000-0002-2513-9450 \\ e-mail: borowier@uek.krakow.pl}

\section{prof. dr hab. Zbigniew Olesiński \\ Akademia Finansów i Biznesu \\ Vistula w Warszawie \\ Wydział Biznesu i Stosunków Międzynarodowych \\ ORCID: 0000-0001-8682-4315 \\ e-mail: z.olesiński@vistula.edu.pl}

\section{Bibliografia}

[1] Appelo J. (2016), Zarządzanie 3.0; Kierowanie zespołami $z$ wykorzystaniem metod agile, Helion, Gliwice.

[2] Blikle A.J. (2018), Doktryna jakości. Wydanie II turkusowe. Rzecz o turkusowej samoorganizacji, Helion, Gliwice.

[3] Borowiecki R., Siuta-Tokarska B. (2008), Problemy funkcjonowania i rozwoju małych i średnich przedsiębiorstw w Polsce; synteza badań i kierunki działania, Difin, Warszawa.

[4] Goldman S.L., Nagel R.N., Preiss K. (1995), Agile Competitors and Virtual Organizations: Strategies for Enriching the Customer, Van Nostrand Reinhold, New York.

[5] Juchnowicz M. (2017), Organizacja samoangażujaca $w$ realiach polskich, „Edukacja Ekonomistów i Menedżerów: Problemy, Innowacje, Projekty”, Nr 3(45), s. 11-22.

[6] Kalwa-Rojczyk A. (2018), Funkcjonowanie turkusowych organizacji w kontekście kompetencji pracowniczych, Studia i Prace WNEiZ US, Nr 51, s. 45-54.

[7] Kowalczewski W., Kuc R.R. (2016), Dyskusje o zarządzaniu. Dylematy jakości kształcenia na kierunku zarządzanie, Wydawnictwo Ementon, Warszawa.

[8] Kozina A., Pieczonka A. (2017), Negocjacje w turkusowej organizacji, „Zarządzanie i Finanse”, Nr 15, s. 163-176.

[9] Laloux F. (2015), Pracować inaczej, Studio Emka, Warszawa.

[10] Olesiński Z., Rzepka A., Olak A. (2017), Zarzadzanie międzyorganizacyjne $w$ zwinnych przedsiębiorstwach, Texter, Warszawa.
[11] Olesiński Z. (2010), Zarządzanie relacjami międzyorganizacyjnymi, Wyd. C.H. Beck, Warszawa.

[12] Olesiński Z. (2005), Zarządzanie w regionie; Polska - Europa Świat, Difin, Warszawa.

[13] Rzepka A. (2018), Relacje międzyorganizacyjne i kapitał intelektualny jako czynniki rozwoju mikro i małych przedsiębiorstw. Studium na przykładzie wybranych przedsiębiorstw polskich i gruzińskich, Difin, Warszawa.

[14] Rzepka A., Olak A. (2017), Opracowanie badań w województwie podkarpackim, Materiał powielany.

[15] Siuta-Tokarska B. (2015), Podobieństwa i różnice w rozwoju przedsiębiorstw sektora MSP $z$ kapitałem krajowym i $z$ udziałem kapitału zagranicznego w Polsce. Analiza i ocena wyników badań, Difin, Warszawa.

[16] Skrzypek A. (2017), Organizacja turkusowa - szansa na nowa jakość zarządzania,czy utopia? „Problemy Jakości”, Nr 49, s. 2-9.

[17] Ziębicki B. (2017), Organizacja bez „szefów” - współczesna moda czy nowy paradygmat zarzadzania? „Humanizacja Pracy", Nr 4(290), s. 79-92.

\section{In Search for Turquoise Work Conditions in Polish Enterprises}

\section{Summary}

The main objective of the paper to identify social, economic, political, technological mechanisms describing main tendencies of changes in organisational structures and methods as well as the methods of their functioning. The main research question concerns the factors that influence initiating intra-organisational changes towards a transformation into turquoise organisational structures. The research methods used to fulfil the paper's objectives were the critical literature analysis as well as empirical analysis of the research results. The research was conducted in enterprises from the Podkarpackie region. As a result of the considerations the Authors present some concepts of the changes that appeared following the contemporary economic evolution where the domination of services, expansion of Internet (including the Internet of Things) and globalisation processes are observed. Transformations of organisational structures towards turquoise ones, where hierarchical relations are less important, are observed in different-sized organizations although those smaller and more recently created are can be defined as those with less formal relations between employees. However, the self-governing processes may be implemented in other organisations, too. As their management indicates, there is a positive perception of the need for adaptive changes to the volatile conditions of their organisations' functioning.

\section{Keywords}

management and quality sciences, innovation, creativity, self-organisation, turquoise organisation 